\section{SOI: $1.1 /$ TAS DOI: $10.15863 /$ TAS International Scientific Journal Theoretical \& Applied Science}

p-ISSN: 2308-4944 (print) e-ISSN: 2409-0085 (online)

Year: $2015 \quad$ Issue: $12 \quad$ Volume: 32

Published: $30.12 .2015 \quad$ http://T-Science.org
Elnur Latif oglu Hasanov Corresponding member of International Academy of Theoretical and Applied Sciences, Ph.D., Senior specialist of Ganja Department Azerbaijan National Academy of Sciences, Ganja, Azerbaijan 1-hasan@hotmail.com

SECTION 12. Geology. Anthropology. Archaeology.

\title{
ABOUT RESEARCH OF BASIC HISTORICAL-CULTURAL FEATURES OF LOCAL TRADITIONS OF GANJA
}

Abstract: In this scientific work basic features of historic-cultural traditions of Ganja have been investigated on the basis of different scientific sources and innovative methods.

Key words: historical-ethnographic research, Azerbaijan, Ganja, innovative research methods.

Language: English

Citation: Hasanov EL (2015) ABOUT RESEARCH OF BASIC HISTORICAL-CULTURAL FEATURES OF LOCAL TRADITIONS OF GANJA. ISJ Theoretical \& Applied Science 12 (32): 1-4. Soi: http://s-o-i.org/1.1/TAS-12-32-1 Doi: crossef http://dx.doi.org/10.15863/TAS.2015.12.32.1

\section{Introduction}

Investigation of craftsmanship traditions on the basis of local craft wares of Ganja is very important. History and art of Azerbaijan people as rich and colorful as its nature. On decorations of this descriptive art are reflected spiritual world, living style, customs and traditions of our nation. Ganja city during centuries considered as one of the main urban cultures and located on the ancient caravan routes, so merchants, travelers, scientists and cultural workers from different countries of the world visited Ganja, and first of all, their visiting helped our nation to integrate their spiritual values to all mankind civilizations. Ganja is one of the oldest cities and has more than 4000 years old as an urban center. Development of some local handicraft branches in this city historically offered necessary facilities for progress of urban culture. $[1,66]$.

Research of ancient traditional handicraft features of Ganja is very necessary. During middle ages in spheres of gentle and applied art, Ganja of inhabitants of territory, in agriculture life bone was widely applied. Bone products, raw materials that found during investigations in and around Ganja prove, that time bone processing separated from other spheres of craftsmanship. Only deeding investigations in ancient territory of Ganja there were found a lot of samples of combs, agriculture instruments, art and other bane things. These samples of art make more ancient history of city culture of Azerbaijan and in whole play nard. There were found knife handles, rare geometrical decorations, samples of pipe and other instruments here. During excavations there was found bone products that used as raw materials and cutting with pipe. In XI-XIII centuries this sphere of art was developing mostly. This thought is proved with a lot of bone and horn, found in zone of excavation. This period from bone there were prepared buttons, knifes and etc. Found during archeological excavations and used in wooden treatment and knife, showed that at the beginning of XI-XIII centuries in and around of Ganja this sphere of craftsmanship in exist. In this period also were prepared such kind of agriculture instruments as wood shovel, rake and etc. But they didn't reach nowadays [2-4].

During our researches in 2013-2014 years we determined some new scientific arguments and facts in this field. The increase in quantity of handicraftsmen in a city directly has been bundled to population growth. The competition of production of production plants and factories has not reached still serious level and consequently was created a favorable condition for spreading of traditional occupations there. In addition, products of these craft branches have been closely bundled to a life and traditions of the people, and it would be difficult to replace with their factory production. In the specified period of history in Ganja developed basically carpet weaving, weaver's business, craft of the tailor, squeeze men, forge and a jeweler, trades of dyer, the stone mason, the cooper and leather dresser, weapon business and other similar craft branches. Among these crafts especially developed carpet weaving.

To so wide development of carpet weaving promoted availability of raw materials. In addition 
carpets were very widely used in a population lifeboth as furniture, and as a curtain, both as sand bed and as a coating for a floor. In carpet weaving have been held basically women. It has been bundled by that in a Muslim society of the woman preferred to work in house conditions. However also know cases when men were occupied with this craft [3]. Tailors and hatters created both national clothes, and clothes in style of the European fashion. According to the spent explorations there are exact data on wide development of a jeweler in Ganja in the end of XIX century - in a beginning of XX centuries. Jewelers basically fabricated ornaments to order. Among them there was a specification. Development of trading and economic relations of Ganja with the next states promoted recognition of local jewels abroad. As an example it is served by unique samples handmade the Azerbaijan jewelers, stored in museums $[5 ; 6]$. But base - columns, capitals, that are symbols of irreplaceable art, part of columns, different man monuments, masonry art symbols, that have Ganja, agriculture and religious meaning, especially grave monuments and phalluses, collections of different colored (red, brown, black, grey and other rare colored) stamps and symbols of decorations, that were found in Azerbaijan during archeological investigations prove it. These rare discover in and around Ganja are known from the archaeological investigations in ancient cultural, art and trade centers of Azerbaijan.

The best samples of monuments, that concern to stone treatment are consists of column props, mill and gridding stones. In whole there were founded in and around Ganja a lot of samples, that concern to X century. They are consisting of stone figure, mills and column props. But stone equipment, found in Ganja prepared from mill and candlestick. Mill is usually prepared from volcanic, quartz, limestone and basalt. They used for grinding seed, millet, slot and for other aims [7]. We meet mostly mill stones, scales and pumice stone in stone treatment. At the same time there were used hewed stones for decorating buildings. In this period there were prepared decorations from precious stone.

\section{Materials and methods}

All these aspects show, that inhabitant of Middle Ages in and around Ganja from the ancient period did masonry, gridding and stone treatment. This sphere of art in developed middle Ages could be in high level. And rare magnificent architectural monuments in and around Ganja that stay till nowadays, prove it. Traditional textile of art of silk weaving products has a special place in Ganja. In the city formed two main method of silk treatment:

1. Spinning. 2. Winding.

From the point of view silkworm breeding development and its preparing technology there were two main forms of production: so-called raw silk weaving and felt weaving .In this important technological processes it has such kind of production stages as cocoon opening, silk initial processing, preparing of raw silk, weaving technology, painting and decoration. In the ancient Ganja during the stage of the Middle Ages the great progress of silkworm was represented by raw silk weaving. For this reason, on the basis of local traditions production of delicate silk textiles from raw silk.

There were made such kind of important samples of art as atlas and kelaqai (silk kerchief). We must pay attention to the moment that differs from the other silk fabrics, kelaqai was prepared by specialists. But distinctly of production of raw silk that was city silkworm breeding and was man activity, felt production was woman work.

In Ganja, that know as the ancient cultural center, the saddle-making handicraft differed from others with rich old traditions. First time preparation of the vehicles was house profession. But afterwards saddle preparation needed of qualified skilled masters, so a new type of art saddle-making, started to form. Historically the traditional art of saddlemaking in Ganja developed in direction of cargo and passenger saddle making. The art of saddle-making within the local saddle-types and their components were determined on a specialization. The production of cargo or pack -saddle a rule was engaged by packsaddle maker. For this reason, in most cases, the profession was called trade of pack-saddle maker [8]. Afterwards military, economic and transportation significance of hoarse was decrease, the demand for goods of saddle-making also was decrease. The reason of primitive saddle-making decreasing was wide sale of cheaper factory products.

History and art of Azerbaijan people as rich and colorful as its nature. On decorations of this descriptive art are reflected spiritual world, living style, customs and traditions of our nation. These pearls of art on material preparing and processing techniques are divided into different kinds. Among these types of craft metal treatment is mostly developed and has ancient history. Abundance of local raw materials created favorable conditions for development of metal treatment from ancient times. In general, in the third millennium BC there was high culture of the Bronze Age in our country, and in the first millennium transition period from Bronze Age to Iron Age began. In that period in Azerbaijan there were appeared several branches of metallurgy treatment. Jewelries, daggers, arms, copper products and other samples of art have been treated so refined, that in nowadays they are protected as very valuable exhibits in famous museums in such cities, as Paris, London, Brussels, Istanbul, Tehran and other cities.

There is no any source about glass production in and around Ganja. The majority of archaeologists 
agreed with the idea, that the homeland of glass production is ancient Egypt, but the famous English archaeologist, Egyptologist Petri Flinders thought, that it could be Mesopotamia or the Caucasus. Taking into account that cobalt, used in glass coloring wasn't in Egypt, the scientists thought that, it could be in the Caucasus, also in Dashkesan. The majority of containers and the analysis based on graphical elements of the Roman scholars came to the opinion that the samples of the same scale as the Roman Empire through trade. There are more than 2000 beads in complex materials. Colored beads have prepared of different types products. Mostly distinguish beads that prepared from blue green and grey paste. A group of beads made of bone and antimony. In III-V centuries, the local craftsmen themselves also became to produce better-designed containers. Among the local clay and glass utensils that found in and around Ganja there were big similarity in the form and also in the decoration. All the glass dishes found in and around Ganja are similar with the local clays on decoration of that period. Glass dishes were containing of Iron, cobalt, magnesium and other elements, that were specific elements for Ganja and its surroundings.

\section{Conclusion and Recommendations}

The development history of this sphere of craftsmanship can be determined only through archaeological research. In general, information about the development of this sphere of was found in 1959-1960 years, glass products in and around Ganja was obtained only at the end of the twentieth century. Results of archaeological excavations in the territory of Azerbaijan and research show that in the preparation of glass utensils were two technical methods: casting method and the method of blowing. The first of these methods is more ancient, but in the Early Middle Ages and Middle Ages were used both of them. Produced glass alloys were transparent colored. By the addition of dusts of various metals in glass alloys people got colored glasses. We can see also to get her with different tinted green glasses also parts of blue, black and pink colored glass dish in sections of IX-X centuries.

Among decorations of that period yellow, white and red beads of round and plain form are met mostly. At the beginning of X-XIII centuries development of production of glass in and around Ganja characterized by improvement from the technology point of view. Archaeological researches show, that outside of the cities in the VIII-IX centuries, also big settlements were established. This is often due to density in cities. From the point of view silkworm breeding development and its preparing technology there were two main forms of production: so-called raw silk weaving and felt weaving. In these important technological processes it has such kind of production stages as cocoon opening, silk initial processing, preparing of raw silk, weaving technology, painting and decoration. In the ancient Ganja during the stage of the Middle But distinctly of production of raw silk that was city silkworm breeding and was man activity, felt production was woman work. In Ganja, that know as the ancient cultural center, the saddle-making handicraft differed from others with rich old traditions. First time preparation of the vehicles was house profession. But afterwards saddle preparation needed of qualified skilled masters, so a new type of art saddle-making, started to form. Historically the traditional art of saddle-making in Ganja developed in direction of cargo and passenger saddle making. The art of saddle-making within the local saddletypes and their components were determined on a specialization. The production of cargo or pack saddle a rule was engaged by pack-saddle maker. For this reason, in most cases, the profession was called trade of pack-saddle maker.

Afterwards military, economic and transportation significance of hourse was decrease, the demand for goods of saddle-making also was decrease. The reason of primitive saddle-making decreasing was wide sale of cheaper factory products. Ganjabasar is one of the richest areas from archaeological point of view. As a result of archaeological investigations here were found samples of material culture that concerned to the stages of different history period. Today most of them are kept in various museums of the world.

The formation of pottery on the territory of ancient Ganja is concern to the stages of ancient history. Basis on research works carried out by the various persons in XIX century and expertsarcheologists at the beginning of XX century in old ruins of the city and surrounding areas there were found different samples of pottery. First of all, there have been discovered, that initial ceramic production in Ganja and its surrounding regions are belong to the VIII-VII millennium BC. From the history point of view, these ancient clay vessels, belonging to the Neolithic stage, are differing from the pottery samples of the neighboring ethnic in number characteristics. These differences are seen in preparing technology, also in the area of external surface decoration.

In this historical period in Ganja and its regions ceramic has following kinds:

1. Building ceramic materials.

2. Unglazed ceramic products.

3. Glazed ceramic products.

For Middle Ages and New period among pottery products of Ganja ceramic samples as clay construction materials have great importance. First of all, glazed bricks that used in construction of most buildings in the XVII-XVIII centuries, and also in great monuments and the main construction material- 
air-dried bricks, attracted attention. In addition to the found samples in residential areas as a result of archaeological excavations, also were found a lot of brick spoilages. According to such kind mass finding of brick spoilages, we can make the conclusion, that the bricks used in construction of buildings in Ganja, were wares of local production. In the territory of Azerbaijan the oldest samples of wood treatment were found in the territory of ancient Ganja. Around Ganja area - in the region of Lake Goy-gol in the IVIII millennium BC have been discovered wooden thicker board, also wooden sugar bowl, that concern to the end of the II millennium $\mathrm{BC}$, found in Mingachevir pitcher grave are material evidences of science thoughts [11]. The majority of historical monuments, that are demonstrate the 4000 thousand year history of Ganja, which is the national wealth of our people, today gain unique place in the expositions of world's museums. In state and private museums of Metropolis, Munich, Berlin, Hamburg, Louvre, Paris, Moscow, St. Petersburg and other cities rare and valuable exhibits, that concern to the history of ancient Ganja are preserved [7].

Made of precious metals gold and silver jewelries, that prepared by Ganja masters, are divided into such four groups for wearing and putting as neck jewelries - it is included such kind of jewelries, that gold piece coin, imperial, cardamom or barley, bracelets, different kinds of beads and etc., jewelries for arms and fingers - this group include bracelets, bangles and rings with various precious stones, head jewelries - skull-cap and others., also jewelries for clothiers [1-3].

As in many places, production of wool, cotton and silk in and around Ganja made necessary emergence and development of weaving. Becoming weaving one of the ancient spheres of crafts in and around Ganja was connected with the rich raw material base here. Presence of useful plant species for textile, including cotton, high level development of wool area of agriculture- sheep and goat breeding, camel breeding, horse breeding, presence of cotton cropping in Middle Ages and finally, regular expansion of silkworm breeding in this area created a foundation for growth of weaving here. In traditional production of cloth manufactory trade historically played an important place [5-8].

On a ground classifying crafts it has been defined that by the end of XIX century a number of fashionable trades began to disappear. Among them were wool-carder, hatcheller, selsbchy, dhulfachy, carriers. They have got rid of and have been replaced by representatives of new crafts. Distribution of experts of certain crafts on quarters and neighboring communes was prominent of crafts. For example, it is possible to recollect. In these neighboring communes functioned craft departments [7-9].

\section{References:}

1. Guliyeva NM, Hasanov EL (2013) Investigation of basic decorative-applied arts of Ganja on the basis of some innovative arguments and technologies. Science and Society: Proceedings of the 3rd International scientific-practical conference. - London: SCIEURO (Great Britain), pp. 281-291.

2. Ohmədov FM (1998) Gəncənin tarix yaddaş1. 1-ci nəşr. Bakı: Şirvannəşr, 198 p.

3. Taylor PM, Hasanov EL (2013) Ethnological features of cultural heritage of Ganja (On the basis of Mahsati Ganjavi's creation). International scientific journal Theoretical \& Applied Science, № 12 (8). pp. 41-44.

4. (2008) Azərbaycan arxeologiyası: 6 cilddə, VI cild. Bakı: Şərq-Qərb nəşriyyatı, 632 p.

5. Hasanov EL (2013) About fundamental studies on local cultural traditions of Ganja. European Journal of Natural History (Fundamental researches: Proceedings of International scientific conference. - Jordan, Aqaba), № 3. pp. 65-68.

6. (1974) The dawn of Art. Leningrad: Aurora Art Publishers, 196 p.
7. Hasanov EL (2013) Innovative approach to teaching and research of some traditional craft branches of Ganja of the end of XIX century. International Journal of Experimental Education (Problems of international integration of national education standards: Proceedings of International scientific conference. - France, Paris), № 2. pp. 81-83.

8. Həsənov EL (2012) Gəncə İmamzadə türbəsi (tarixi-etnoqrafik tədqiqat). 1-ci nəşr. Bakı: Elm və təhsil, $268 \mathrm{p}$.

9. (2007) Azərbaycan etnoqrafiyası: 3 cilddə, I cild, Bak1: Şərq-Qərb, 544 p.

10. Hasanov EL (2014) Innovative basis of research of local handicraft branches of Ganja of the second half of XIX - beginning of XX centuries. Mediterranean Journal of Social Sciences, vol. 5, № 23, Part IV, pp. 2359-2362. Doi:10.5901/mjss.2014.v5n23p2359

11. Hasanov EL (2014) To the question on the research of typical features of craftsmanship heritage of Ganja of the late XIX - early XX centuries. ISJ Theoretical \& Applied Science 12(20): 27-30. doi: http://dx.doi.org/10.15863/TAS.2014.12.20.7 